\title{
LINGUISTIC IDENTIFICATION OF AN EMAR SCRIBE
}

\author{
Jun IKEDA*
}

Recently an Akkadian tablet held privately in Tokyo was published by Dr. Akio Tsukimoto. (1) We will call it below "the Miyazawa tablet" after the name of the collector. As Tsukimoto mentioned, it evidently originates from Emar (modern Meskene-Qadime) on the middle Euphrates. Emar was excavated by a French expedition from 1972 to 1976 until it was submerged into a dam. (2) Nearly eight hundred Akkadian texts were unearthed at Emar and published by Daniel Arnaud. (3) Besides, there are more than two hundred Akkadian tablets, published here and there by several scholars, as those from the vicinity of Emar and from the middle Euphrates region, (4) part of which are apparently from Emar.

The Miyazawa tablet was written by a scribe by the name of Abi-Kapi. Abi-Kapi, as Tsukimoto pointed out, (5) is a well-known scribe in Emar. He wrote twelve texts in addition to the Miyazawa tablet, i.e. RPAE 4, 14, 126, 144, 156, 157, 159, ASJ 12 7, TSABR 3, 6, 8, 9. Among them RPAE 14, 144, 156 and TSABR 3 bear the name of dŚKUR-GAL as the first witness; RPAE 126, TSABR 6 that of Abbanu; and RPAE 4, 157, 159, ASJ 12 7, TSABR 9 that of Pilsu-Dagan. Note that all three are members of the royal family, (6) which can be reconstructed as follows :

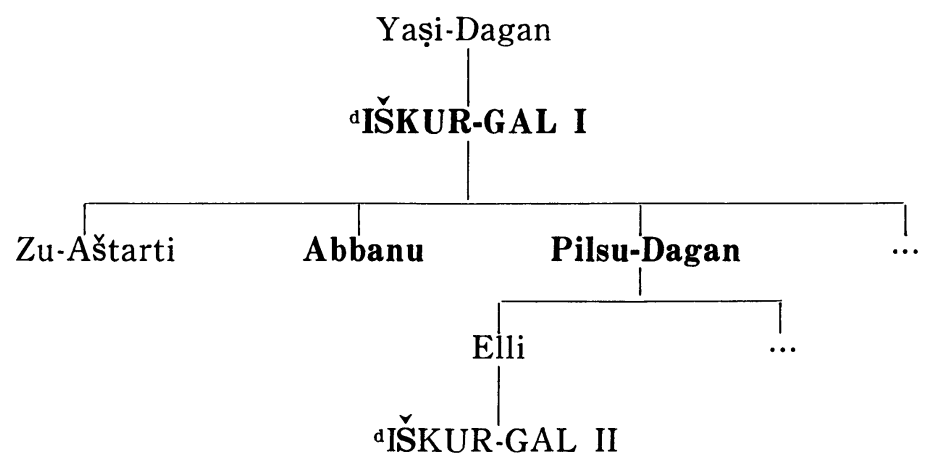

* Graduate Student, Tel Aviv University

Vol. XXVIII 1992 
The first witness of the Miyazawa tablet is dŠKKUR-GAL son of Elli. (7) It follows that Abi-Kapi's scribal career extended over four generations. (8) Was Abi-Kapi extraordinary long-lived, or were there two scribes with the same name?

Linguistic evidence supports the latter view. The Miyazawa tablet is distinct from the other texts written by Abi-Kapi in the following respects:

1. SAG.KI (ll. 9 and 10) is followed by the IGI sign. This is not the case with the other texts that Abi-Kapi wrote (cf. ASJ $127: 26,27$; TSABR $3: 8,9 ; 6: 7,8 ; 9: 7,8)$. Moreover, if the $I G I$ sign is a pronominal suffix + $\check{i} i$ referring to eqlu "field", there should be a sort of gender-switching between $l l$. 5 and 8.(9) Although a similar phenomenon is attested in ASJ 126 (written by Dagalli), eqlu is consistently treated as masculine in the other texts written by Abi-Kapi (cf. $A S J$ 12 7, TSABR 3, 6, 9?).

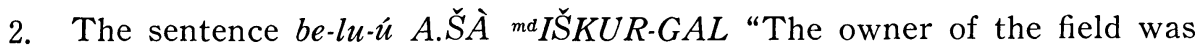
PN" (l. 11) describes the previous ownership of the field. Such wording is unattested in the other texts written by Abi-Kapi. $\mathrm{X} \check{\text { s }} a \mathrm{Y}$ "X was Y's" (X=a sold item; Y=its previous owner) is used instead (RPAE $126: 7 ; 144: 8-9 ; 159: 9-10 ;$ ASJ $127: 8,28 ;$ TSABR $3: 10 ; 6: 9 ; 8$ : $9 ; 9: 18)$.

3. The nominalizer mannu(m)me "whoever" (l. 23) is unattested in the other texts written by Abi-Kapi. A similar curse is attested in ASJ $127: 47-50$ and $T S A B R \quad 9: 44-48$. In both cases the relative particle $\check{s} a$ is used instead of mannu(m)mē.

4. sahāru D "to turn away" (l. 24) in the curse formula stands in contrast to nakāru D "to change (an agreement)" (ASJ $127: 47$; TSABR 9:44).

5. The $L I$ sign of the Miyazawa tablet is written with three horizontal wedges as in Old Babylonian ( 4 ), while that of the other texts written by Abi-Kapi has two horizontal wedges as in Middle Babylonian

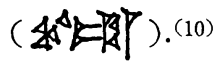

It thus looks quite plausible to assume that there were two different scribes by the mame of Abi-Kapi, i.e. Abi-Kapi I (contemporary with dISKKUR-GAL I, Abbanu and Pilsu-Dagan) and Abi-Kapi II (contemporary with dísKUR-GAL II).

It is worth noting here that the language of Abi-Kapi II is different not only from that of Abi-Kapi I but also from that of the Emar royal documents, 
viz. texts bearing a name of a member of the Emar royal family. SAG.KI-ši, a sentence of the type : be-lu- $u$ X Y (X=a sold item; Y=its previous owner), mannu $(m) m \bar{e}$ and the D stem of sahāru for the curse formula(11) are nowhere attested in the Emar royal documents. The most distinctive among them is $m a n n u(m) m \bar{e}$. It is widely attested in peripheral Akkadian, (12) but somehow absent from the Emar royal documents. The fact that Abi-Kapi II did use $m a n n u(m) m \bar{e}$ indicates that he had a different scribal tradition from the royal scribes of Emar. ${ }^{(13)}$

\section{Notes}

(1) A. Tsukimoto, An Akkadian Field Sale Document Privately Held in Tokyo, Acta Sumerologica 14 (1992), pp. 311-315.

(2) The discoveries of the excavations are summarized in D. Beyer (Ed.), MeskénéEmar: Dix ans de travaux 1972-1982, Paris, 1982.

(3) D. Arnaud, Recherches au pays d'Aštata - Emar VI. 1-4, Paris, 1985-1987 (abbr. RPAE).

(4) M. Sigrist, Miscellanea, JCS 34 (1982), pp. 242-252. J. Huehnergard, Five Tablets from the Vicinity of Emar, $R A 77$ (1983), pp. 11-43. J.-W. Meyer und G. Wilhelm, Eine spätbronzezeitliche Keilschrifturkunde aus Syrien, Damaszener Mitteilungen 1 (1983), pp. 249-261. D. Arnaud, La Syrie du moyen-Euphrates sous le protectorat hittite: l'administration d'apres trois letters inédites, Aula Orientalis 2 (1984), pp. 179-188. A. Tsukimoto, Eine neue Urkunde des Tili-Šarruma, Sohn des Königs von Karkamiš, ASJ 6 (1984), pp. 65-74. D. Arnaud, La Syrie du moyen-Euphrates sous le protectorat hittite: contrats de droit privé, Aula Orientalis 5 (1987), pp. 211-241. G. Beckman, Three Tablets from the Vicinity of Emar, JCS 40 (1988), pp. 61-68. A. Tsukimoto, Sieben spätbronzezeitliche Urkunden aus Syrien, ASJ 10 (1988), 153-189. A. Tsukimoto, Akkadian Tablets in the Hirayama Collection (I), ASJ 12 (1990), pp. 177-259. D. Arnaud, Textes Syriens de l'âge du bronze récent, Barcelona, 1991 (abbr. TSABR). A. Tsukimoto, Akkadian Tablets in the Hirayama Collection (II), ASJ 13 (1991), pp. 275-333. A. Tsukimoto, Six Texts from the Middle Euphrates Region, ASJ 13 (1991), pp. 335-345. A. Tsukimoto, Akkadian Tablets in the Hirayama Collection (III), ASJ 14 (1992), pp. 289-310. A. Tsukimoto, loc. cit (note 1 above).

(5) A. Tsukimoto, loc. cit. p. 313 , notes on $l .36$.

(6) For the royal family of Emar, see D. Arnaud, Les textes d'Emar et la chronologie de la fin du Bronze Récent, Syria 52 (1975), pp. 87-92; and F. M. Fales, Notes on the Royal Family of Emar, in: D. Charpin et F. Joannès (Eds.), Marchands, diplomates et Empereurs: Études sur la civilisation Mésopotamienne offertes à Paul Garelli, Paris, 1991, pp. 81-90.

(7) Note that the Miyazawa tablet shares at least two witnesses with RPAE 144 and TSABR 3: ad-di-ia DUMU da-da (Miyazawa Tablet l. 28; PRAE $144: 28$; TSABR $3: 26$ ) and še-um!'(Tsukimoto: ka)-ma DUMU la-a-la (Miyazawa Tablet l. 33; PRAE $144: 30 ; T S A B R 3: 30$ ). This suggests that dŠKUR-GAL son of Elli in the Miyazawa tablet and dŠKUR-GAL son of Yași-Dagan in RPAE 144 and TSABR 3 may well be the same person. A reevaluation is needed of the genealogy of the Emar royal family.

(8) It is known to the present writer that there is an unpublished tablet bearing 
the names of Abi-Kapi, the scribe, and Yași-Dagan, the father of dŠKKUR-GAL. If the readings of these names are correct, Abi-Kapi's scribal career turns out to extend over five generations, which is practically impossible.

(9) eqlu is referred by $+\check{s} u$ ( $l l .3$ and 4) and modified by annâ (l. 18).

(10) Based on the photograph ( $A S J 127$ ) and Arnaud's hand copies ( $P R A E$ and $T S A B R)$.

(11) Cf. A. Tsukimoto, loc. cit. p. 313, notes on ll. 23-26.

(12) E. g. Ugarit, Boğazköy, Carchemish, Amurru, Alalah̆ and Nuzi (cf. $A H w$, p. $603 \mathrm{~b})$.

(13) Note that another scribe by the name of Abi-Kapi is attested in Tall Munbāqa. Cf. W. Mayer, Der antike Name von Tall Munbāqa, die Schreiber und die chronologische Einordnung der Tafelfunde: Die Tontafelfunde von Tall Munbāqa 1988, MDOG 22 (1990), pp. 45-66. 